\title{
IMPLEMENTASI MODEL SUPERVISI BERBASIS KEIKHLASAN DALAM PENINGKATAN KINERJA GURU PAI DI SMP NEGERI KABUPATEN NAGAN RAYA

\author{
Herman ${ }^{1}$, Jamaluddin Idris ${ }^{2}$
}

\begin{abstract}
ABSTRAK
Model supervisi berbasis keikhlasan merupakan salab satu model supervisi menjadikan nilai-nilai kekhlasan sebagai prinsip dasar dalam bekerja, membangun jati diri dalam bertindak dan berbuat, dan menjadi kekuatan moral bagi pengawas PAI pada saat mengoperasionalkan tugas pokok dan fungsi (Tupoksi) supervisi kepada guru PAI. Permasalahan yang ditemukan di lapangan bahwa pengawas $P A I$ masih jauh dari sikeap dan perilaku keikhlasan pada saat membimbing, membina, dan memperbaiki kinerja guru PAI. Penelitian ini menggunakan metode "deskriptif", dengan pendekatan kualitatif dan pola fikir induktif terhadap peristiwa, gejala atau fenomena alamiah yang dijumpai di lapangan. Pengumpulan data dilakukan melalui: observasi, wawancara, dan studi dokumentasi. Selanjutnya teknik analisis data mengacu pada pendapat Miles dan Huberman dengan cara melakukan reduksi data, penyajian data, dan penarikan kesimpulan. Pemeriksaan keabsahan data dilakukan melalui triangulasi sumber, triangulasi metode, dan triangulasi teori. Hasil penelitian menunjukkan bahwa pengawas PAI sudah mengimplementasikan nilai-nilai keikhlasan pada saat mengoperasionalkan tupoksi supervisi kepada guru PAI melalui model takut kepada kemasyhuran, dan sanjungan karena membawa fitnah, model menganggab dirinya bina dibadapan-Nya, model menyukai amal kebaikan secara senbunyi-sembunyi, model tidak mencari keuntungan dalam bekerja, dan model senang terhadap orang yang melebibi dirinya. Sedangken dari segi efektifitas model supervisi berbasis keikhlasan ini belum menunjukan hasil yang optimal terhadap peningkatan kinerja guru PAI, karena pengawas $P A I$ masib lemah menjunjung tinggi nilai-nilai keikhlasan dalam bekerja.
\end{abstract}

\section{Kata Kunci: Model Supervisi, Keikhlasan, dan Kinerja Guru PAI}

1 Dosen pada Sekolah Tinggi Agama Islam Negeri Teungku Dirundeng Meulaboh, Email: herman@staindirundeng.ac.id

2 Guru Besar UIN Ar-raniry Banda Aceh, email: Jamaluddin_idris@arraniry.ac.id 


\section{Pendahuluan}

Berbicara masalah pendidikan, tentu tidak terlepas dari masalah supervisi pendidikan. Karena tugas pokok, dan fungsi (tupoksi) supervisi pendidikan merupakan usaha untuk meningkatkan kinerja guru. Secara umum tupoksi pengawas adalah membantu, membina dan memperbaiki kinerja guru, termasuk kepala sekolah, dan tenaga kependidikan lainnya, guna meningkatkan efesiensi, efektivitas, dan produktivitas penyelenggaraan pendidikan, dan pengajaran di sekolah (Akhmad Sudrajat, 2009: 1). Semakin tinggi andil pengawas dalam membantu dan memperbaiki kinerja guru, maka semakin berkualitas pendidikan di sekolah.

Pelaksanaan supervisi pada hakikatnya untuk memberikan bimbingan profesional kepada guru dalam melaksanakan tupoksi sebagai seorang guru (Farid Mashudi, 2013: 325). Pengawas selaku supervisor dapat berperan sebagai konsultan dalam mengelola dan memimpin guru dalam pelaksanaan tugasnya, dan menjadi stimulator bagi guru dalam menggerakkan dan meningkatkan produktivitas kerjanya. Untuk itu seorang pengawas tidak cukup memiliki kompetensi manajerial saja, tetapi juga harus mampu merancang, dan melaksanakan program supervisi secara komprehensif dalam upaya peningkatan kinerja guru di sekolah.

Pengawas PAI pada saat melaksanakan supervisi tidak hanya sekedar untuk meningkatkan kualitas mengajar guru semata, melainkan yang paling esensi adalah bagaimana mengembangkan potensi guru PAI, agar mareka dapat bekerja secara profesional dalam bidang profesinya (Ali Imron, 2011: 10). Karena sasaran akhir dari pelaksanaan supervisi kepada pendidik, dan tenaga kependidikan lainnya adalah untuk memberikan pelayanan, bantuan, dan perbaikan-perbaikan kearah yang lebih baik dan maju kedepan (Piet A. Sahartian, 2006: 19).

Pengawas PAI selaku supervisor dalam menjalankan tupoksi supervisi kepada guru PAI, harus tampil dengan segenap jiwa keikhlasan dalam mengkoordinasikan, membimbing, dan membina profesi guru secara kontinu, dan komprehensif, baik secara individual maupun secara kelompok (Mukhtar \& Iskandar, 2009: 40-41). Pengawas PAI yang memiliki jiwa keikhlasan selalu mencurahkan pengetahuan, keterampilan, dan pengalaman untuk membangun dan mengembangkan potensi guru PAI, agar mareka dapat menyusun rencana program pembelajaran yang berkualitas, pelaksanaan proses pembelajaran yang menyejukkan dan menyenangkan, serta dapat memberikan penilaian pembelajaran yang valid dan representatif, serta dapat mengembangkan profesi dirinya secara kontinu dan up to date (Departemen Agama RI, 2005: 847).

Pengawas PAI yang sukses dalam bekerja tetap selalu menjunjung tinggi nilai-nilai keikhlasan pada saat membimbing, membina, dan 
memperbaiki kinerja guru serta mengembangkan profesi guru menuju guru yang profesionalitas, dan profesionalisasi dalam bidang mendidik, mengajar, dan membimbing anak didik kearah kedewasaan, sebagaimana firman Allah berbunyi:

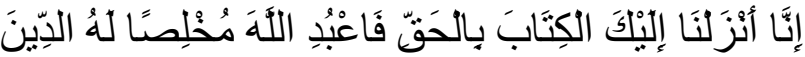

Artinya: 'Sesungguhnya Kami menurunkan kepadamu kitab (Al Qur'an) dengan (membawa) kebenaran. Maka sembahlah Allah dengan memurnikan ketaatan kepada-Nya" (QS.Az-Zumar:2-3)

Beranjak dari ayat tersebut diatas, pengawas PAI yang berjiwa mukblisin selalu memurnikan ketaatan kepada-Nya, dan sangat takut kepada kemasyhuran dalam bekerja, dan selalu berusaha menjauhkan diri dari sanjungan manusia yang dapat membawa fitnah kepada dirinya. Kemudian dalam melakukan kebaikan dan menegakkan kebenaran selalu dengan sembunyi-sembunyi, dan tidak ada niat untuk dipamirkan atau apa lagi untuk diekpos.

Pengawas PAI yang ikhlas beramal sangat konsisten dan komitmen untuk mengimplementasikan nilai-nilai keikhlasan pada saat mengoperasionalkan tupoksi supervisi kepada guru PAI, karena nilai-nilai keikhlasan akan terbentuk prinsip-prinsip dalam bekerja, jati diri dalam bertindak dan berbuat, serta menjadi kekuatan moral (moral force) bagi pengawas PAI dalam menjalankan tupoksi supervisi kepada guru PAI (Agus Maimun dan Agus Zainul Fitri, 2010: 83). Melalui implementasi nilai-nilai keikhlasan akan tumbuh dan berkembang jiwa keikhlasan dalam bekerja, tidak mengharap pamrih, dan pujian serta sanjungan dari orang lain., dan selalu berpegang teguh pada syariat agama, dan ketentuan pemerintah.

Sekarang sangat sedikit ditemui di lapangan, pengawas PAI yang memiliki jiwa keikhlasan pada saat mengoperasionalkan tugas pokok, dan fungsi (tupoksi) supervisi kepada guru PAI, sehingga sikap dan perilaku mareka jauh dari kriteria atau ciri-ciri keikhlasan sebagai berikut: 1) takut kemasyhuran, dan sanjungan yang dapat membawa fitnah, 2) menganggap dirinya hina di hadapan-Nya, 3) menyukai amal kebaikan secara sembunyisembunyi dari pada dipamirkan, 4) bekerja bukan untuk mencari keungtungan, tetapi mencari keredhaan-Nya, dan 5) merasa senang terhadap orang-orang yang melebihi dirinya.

Berdasarkan permasalahan tersebut, penulis ingin mengetahui bagaimana mengimplementasi model supervisi berbasis keikhlasan yang diterapkan oleh pengawas PAI pada saat mengoperasionalkan tupoksi supervisi peningkatan kinerja guru PAI. Penelitian ini berfokus pada pendekatan keikhlasan yang dijadikan sebagai model peningkatan kinerja 
guru PAI. "Karena dengan pengamalan nilai-nilai keikhlasan dalam bekerja akan tergerak jiwa dan hati untuk bekerja dengan tulus ikhlas, sepenuh hati, segenap jiwa dan raga, serta bekerja dengan penuh disiplin dan tanggung jawab serta terbebas dari penyimpangan terhadap pelaksanaan tupoksi supervisi kepada guru PAI" (O Sholehuddi, dkk, 2009: 13).

Melalui kajian implementasi model supervisi berbasis keikhlasan diharapkan dapat membawa manfaaat bagi pengawas PAI dalam menemukan, dan menerapkan cara-cara mengaplikasikan model supervisi berbasis keikhlasan dalam peningkatan kinerja guru PAI. Kemudian bagi pakar pendidikan, dan pemerhati pendidikan dapat menambah wawasan, dan pengalaman baru dalam megembangan teori model supervisi dalam dunia pendidikan dewasa ini.

\section{Landasan Teoritis}

\section{Makna Keikhlasan}

Nilai keikhlasan salah satu nilai religius yang dijadikan sebagai landasan terbentuknya sikap dan perilaku keikhlasan bearamal. Bila seseorang tidak memiliki jiwa keikhlasan dalam bekerja, maka mustahil dapat terbentuk sikap keikhlasan dalam bekerja (Muhammad Fathurrohman, 2015: 52). Nilai keikhlasan adalah sebuah nilai yang paling ampuh dalam memurnikan tujuan ibadah untuk mencari keridhaan-Nya. Murni beribadah dan beramal adalah tidak mencampur adukkan dengan tujuan-tujuan lainnya (Fadhlina Arief Wangsa, 2012: 42).

Menurut Qalami dalam Chizanah, ikhlas merujukkan pemurnian niat dalam menjalani rutinitas kehidupan, hanya untuk mencari kedekatan kepada-Nya (Lu'luatul Chizanah, 2011: 146). Ikhlas adalah menghendaki keridhaan-Nya dengan sesuatu amal, membersihkan dari segala noda duniawi. Tidak ada yang melatar belakangi suatu amal kecuali karena-Nya semata (Yusuf Al-Qardhawy, 1997: 17). Hal ini sejalan dengan firman Allah berbunyi:
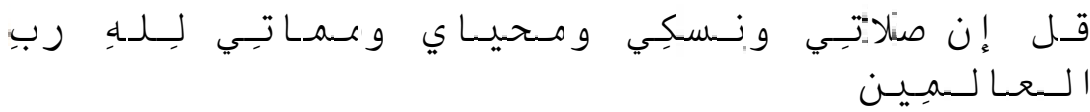

Artinya: "Sesungguhnya shalatku, ibadahku, hidupku, matiku lillahi rabbil'alamin." (QS. Al-An'am (6): 162)

Berdasarkan ayat tersebut diatas dapat dijelaskan bahwa, apapun pekerjaan yang dilakukan harus semata-mata karena-Nya, mulai dari niatnya sampai pada pengawasan dan penilaian dilakukan oleh-Nya. Kemudian selalu menganggab dirinya hina dihadapan-Nya pada saat 
bertindak dan berbuat yang dapat mendatangkan kebaikan dan kebenaran untuk dirinya dan publik.

\section{Kriteria atau Ciri-Ciri Orang Ikhlas}

Menurut pendapat Ustad Jeffry kriteria atau ciri-ciri orang ikhlas adalah sebagai berikut: Pertama, takut kepada kemasyhuran, dan sanjungan yang dapat membawa fitnah kepada diri sendiri, dan agamanya, kedua, senantiasa menganggap dirinya hina dihadapan-Nya, dan tidak dirasuki sifat takabur, dan takjub terhadap diri sendiri, ketiga, menyukai amal kebaikan dilakukan secara sembunyi-sembunyi dari dipamirkan atau diekpos, keempat, bekerja semata-mata untuk mencari keredhaan-Nya, bukan untuk mencari keungtungan, dan kemewahan duniawi semata, dan kelima, merasa gembira dengan adanya orang-orang yang mempunyai kemampuan melebihi dirinya (Ustad Jeffry, tth: 1-5).

Berdasarkan pendapat, penulis menetapkan 5 (lima) kriteria atau ciri-ciri keikhlasan yang dijadikan sebagai model supervisi berbasis keikhlasan peningkatan kinerja guru PAI, yaitu: 1) takut kepada kemasyhuran dan sanjugan karena dapat membawa fitnah, 2) menganggab dirinya hina dihadapan-Nya, 3) menyukai amal kebaikan secara sembunyi-sembunyi dari pada di pamir-pamirkan, 4) bekerja semata-mata mencari keredhaan-Nya, dan 5) merasa senang, dan gembira terhadap orang yang melebihi darinya.

\section{Metode Penelitian}

Jenis penelitian ini dalam bentuk "deskriptif", dengan pendekatan kualitatif. Penelitian ini dilaksanakan selama 2 (dua) bulan, sejak bulan Desember 2018 sampai dengan bulan Januari 2019 di ruang pengawas PAI Kantor Kementerian Agama Kabupaten Nagan Raya dan di SMP Negeri Kabupaten Nagan Raya, dengan jumlah responden 23 orang, terdiri dari 2 (dua) orang pengawas, 1 (satu) Kasi Pendis, dan 20 (dua puluh) orang guru PAI. Instrumen pengumpulan data melalui: a. Observasi, yaitu pengamatan secara langsung tentang kondisi, gejala dan perilaku pengawas PAI dan guru PAI di SMP Negeri kabupaten Nagan Raya, b. Wawancara, yaitu melakukan wawancara dengan pengawas PAI, Kasi Pendis dan guru PAI, sesuai kisi-kisi instrumen yang telah dirancang sebelumnya, dan c. Dokumentasi, yaitu melakukan penelusuruan terkait dokumen berupa program kerja dan profil pengawas PAI. Sedangkan teknik analisis data menggunakan pendapat Miles dan Huberman dengan cara melakukan: a. Reduksi, yaitu proses pemilihan, penyederhanaan, dan pengabstrakan, b. Penyajian data, yaitu menyusun, dan menggabungkan informasi secara 
padu pada saat menyajikan data dalam bentuk narasi, tabel, gambar, dan bagan, dan c. Penarikan kesimpulan secara rinci, kuat, dan mengakar.

Dalam pemeriksaan keabsahan data menggunakan empat macam kriteria, yaitu: a. Kriteria derajat kepercayaan (credibility) dengan cara mengkonfirmasikan data dengan objek penelitian, dengan teknik yang digunakan, yaitu: 1) ketekunan pengamatan (presistent obsersevation), 2) memeriksa keabsahan data dengan memanfaatkan data lain melalui tiga triangulasi data, yaitu: a) triangulasi sumber, b) triangulasi metode, dan c) triangulasi teori. b. Kriteria keteralihan (transferability) adalah membangun keteralihan dengan cara "uraian rinci" dalam mendeskripsikan implementasi model supervisi berbasis keikhlasan, c. Kriteria kebergantungan (dependabiliy) adalah menilai proses penelitian bermutu atau tidak dalam pelaksanaannya, dan d. Kriteria kepastian (confirmability) yaitu menilai hasil penelitian ini apakah bermutu atau tidak terhadap hasil temuan yang diteliti.

\section{Hasil Penelitian Dan Pembahasan}

Untuk mendapat gambaran yang jelas tentang implementasi model supervisi berbasis keikhlasan dalam peningkatan kinerja guru PAI di SMP Negeri Kabupaten Nagan Raya dapat dijelaskan sebagai berikut:

\section{Model Takut Kemasyhuran karena Membawa Fitnah}

Dalam mengoperasionalkan tupoksi supervisi kepada guru PAI sangat diperlukan bekerja dengan tulus ikhlas, supaya tumbuh, dan berkembang semangat kerja, disiplin, dan tanggung jawab terhadap tugas yang diamanahkan kepadanya. Kemudian meyakini kesuksesan dan kegagalan dalam menjalankan tugas supervisi kepada guru PAI ditentukan oleh-Nya, dan dalam bekerja tidak ingin mendapatkan kemasyhuran dan ketenaran, karena takut membawa fitnah.

Data hasil penelitian tentang implementasi supevisi berbasis keikhlasan model takut kemasyhuran, dan sanjungan karena membawa fitnah menunjukkan bahwa: pertama pengawas PAI dalam bekerja senantiasa menunjukkan sikap tulus ikhlas dalam menjalankan tugas pengawasan kepada guru PAI, sehingga dengan sikap tulus ikhlas dalam bekerja sangat menentukan kualitas pelaksanaan tupoksi supervisi kepada guru PAI, kedua pengawas PAI senantiasa meyakini kesuksesan dan kegagalan dalam bekerja ditentukan oleh-Nya, sehingga ia terus berusaha maksimal untuk memperoleh hasil yang memuskan dalam menjalankan tugas supervisi kepada guru PAI, dan ketiga pengawas PAI sangat menghindari diri dari sikap, dan perilaku mengharap kemasyhuran 
dan ketenaran pada saat menjalankan tupoksi supervisi kepada guru PAI, karena ia meyakini kemasyhuran dan ketenaran adalah milikNya.

Dalam upaya mengimplementasikan model supervisi takut kepada kemasyhuran dan sangjungan karena membawa fitnah, maka pengawas PAI di SMP Negeri Kabupaten Nagan Raya perlu melakukan hal-hal sebagai berikut:

a. Bekerja dengan hati yang tulus ikhlas

Pengawas PAI harus mampu menginternalisasikan nilainilai kerja dengan hati yang tulus ikhlas pada saat menjalankan tupoksi supervisi kepada guru PAI, dengan cara pengawas PAI harus memiliki sikap dan perilaku ikhlas dalam bekerja. "Pengawas PAI dalam bekerja harus mencari keridhaan-Nya, dan memurnikan perbuatan dari segala bentuk kesenangan duniawi." (Yusuf Qardawi, 1996: 13) Ia memiliki niat dengan hati yang tulus ikhlas dalam peningkatan kinerja guru PAI.

b. Kesuksesan dan kegagalan kerja ditentukan oleh-Nya

Pengawas PAI harus menyakini betul bahwa kesuksesan dalam bekerja ditentukan oleh-Nya, bukan karena pengawas PAI yang serba bisa atau kurang kuat usahanya, akan tetapi semua itu karena pertolongan, dan kasih sayang-Nya. Kalau terjadi kegagalan, dan kesulitan dalam bekerja bukan juga semata-mata karena kemampuan yang lemah, usaha yang kurang maksimal, itu semua sudah menjadi takdir-Nya.

c. Takut kemasyhuran dan ketenaran

Pengawas PAI yang mampu menginternalisasikan rasa takut kemasyhuran karena dapat membawa fitnah atas dirinya, maka pangkat dan jabatan atau nikmat lain dari-Nya sangat dihidari dari kemasyhuran dengan cara bekerja dengan sembunyisembunyi, bukan untuk mepamirkan diri pada orang lain, karena semua itu dapat mengundang fitnah terhadap dirinya. "Walaupun seseorang merasa memiliki kemasyhuran di seluruh penjuru dunia sekalipun, sedangkan niatnya bercampur baur, maka kemasyhuran itu tidak akan memberi manfaat apapun kepadanya." (Ustad Jeffry, tth: 1-5).

Ketiga indikator tersebut di atas harus dijadikan sebagai prinsip dasar bagi pengawas PAI dalam mejalankan tugas supervisi kepada guru PAI dengan cara bekerja dengan hati yang tulus ikhlas, menyakini kesuksesan, dan kegagalan dalam bekerja ditentukan oleh-Nya serta sangat takut kepada kemasyhuran dan ketenaran terhadap prestasi yang diraihnya. 


\section{Model Menganggab Dirinya Hina Dihadapan-Nya}

Pengawas PAI dalam mengoperasionalkan tupoksi supervisi kepada guru harus jauh dari sikap takabbur dan takjub pada saat meraih prestasi dan perhargaan terhadap tugas yang diembannya. Dalam bekerja harus menggantungkan diri kepadaNya supaya terhindar dari rasa cemas, stress, dan lega hatinya serta tidak terpengaruh dengan ajakan-ajakan yang menyimpang dengan ketentuan agama dan pemerintah. Bekerja jangan mudah tersinggung, dan sakit hati, akan tetapi harus berikap positif kepada orang lain, serta selalu intropeksi diri untuk melakukan perbaikan-perbaikan terhadap kelemahan dirinya sendiri.

Data hasil penelitian tentang implementasi supervisi bebasis keikhlasan model menganggab dirinya hina dihadapan-Nya menunjukkan bahwa: pertama sikap dan perilaku pengawas PAI sangat jauh dari sikap takabbur dan takjub pada saat meraih prestasi dan memperoleh perhargaan terhadap tugas supervisi yang diembannya, karena ia sangat meyakini keberhasilan dan kegagalan dalam bekerja ditentukan oleh-Nya, sesuai dengan tingkat usahanya, kedua sikap dan perilaku pengawas PAI dalam bekerja selalu menggantungkan diri kepada-Nya, supaya terhindar dari rasa cemas dan stress bila belum mendapat hasil yang memuaskan serta membuat hatinya lega, dan tidak terpengaruh dengan ajakan yang menyimpang serta tekanan dari luar aturan yang berlaku, dan ketiga pengawas PAI harus dapat mengontrol diri agar tidak mudah tersinggung dan sakit hati pada saat melaksanakan tupoksi supervisi kepada guru PAI, walaupun ada yang merendahkan martabat dirinya, ia tetap saja berikap positif kepada guru PAI, dan terus melakukan intropeksi diri untuk melakukan perbaikanperbaikan kedepan, serta bersikap bijak sana, dan lembah lembut kepada guru PAI.

Dalam upaya mengimplementasikan model supervisi menganggab dirinya hina dihadapan-Nya, maka pengawas PAI di SMP Negeri Kabupaten Nagan Raya perlu melakukan hal-hal sebagai berikut:

a. Bekerja terbebas dari sifat takabbur, dan takjub terhadap dirinya

Pengawas PAI berkewajiban menjauhkan diri dari sifat takabbur dan takjub terhadap diri sendiri pada saat menjalan tupoksi supervisi kepada guru PAI. Kemudian menginternalisasikan nilai-nilai tersebut supaya terhindar dari sikap dan perilaku yang dapat merusakdan membinasakan 
pribadinya, dan menghapus amal saleh serta mengdapat siksa di negeri akhirat kelak. Bila hal tersebut tidak dihilangkan, maka ia akan selalu memuji dan menyangjung diri sendiri, serta menganggap dirinya yang lebih baik dari pada orang lain.

b. Bekerja menggantungkan diri pada-Nya

Menggantungkan diri kepada-Nya adalah jalan terbaik bagi pengawas PAI dalam melaksanakan tugas supervisi kepada guru PAI. Karena dengan menggantungkan diri kepada-Nya, akan hilang kerisauan dan gundah kalau hilang nikmat duniawi, hilang pangkat dan jabatan akibat tidak menyanggupi bujukanbujukan terhadap hal-hal yang menyimpang dari ketentuan agama dan pemerintah. Penyerahan diri kepada kepada-Nya menjadi faktor pendorong berkerja dengan sepenuh hati, dan mau menerima kenyataan hidupnya. Penyerahan diri bukanlah duduk diam dan bermalas-malasan, akan tapi ia terus bekerja keras dan tuntas terhadap tugas yang diembannya.

c. Bekerja tidak pernah tersinggung dan sakit hati

Pengawas PAI yang berjiwa ikhlas pada saat mengoperasionalkan tupoksi supervisi kepada guru PAI tidak pernah tersinggung, dan sakit hati. Ia senantiasa bersikap hatihati dan waspada agar tidak muncul sikap takabbur, riya, dan sombong terhadap kebaikan yang telah dilaksanakan, sesuai firman-Nya artinya: "Janganlah kamu menganggap diri kamu suci (orang baik) karena Allah-lah yang lebih mengetahui siapa yang benar-benar bertaqwa. (QS; an-Najm: 32)

Ketiga indikator tersebut di atas harus dijadikan sebagai prinsip dasar bagi pengawas PAI, dimana dalam mejalankan tugas supervisi harus senantiasa menganggap dirinya hina dihadapan-Nya agar terhindar dari penyakit angkuh dan sombong dalam bekerja, dengan cara jauhkan diri dari sifat takabbur dan takjub terhadap dirinya, menggantungkan diri kepada-Nya, dan selalu waspada terhadap sifat takabbur dan riya.

\section{Model Menyukai Amal Kebaikan Secara Sembunyi- Sembunyi}

Pengawas PAI yang beriiwa ikhlas tidak menyukai prestasi kerja dipamirkan kepada orang lain, karena dapat mendatang riya, takabbur, keangkuhan dan kesombongan pada diri sendiri dan pada orang lain. Ia tidak senang membanggabanggakan diri sendiri kepada orang lain terhadap apa yang telah 
diperbuatnya, karena sikap dan perilaku yang demikian dapat mengjengkelkan pikiran dan hati orang lain. Kemudian ia selalu muncul di hatinya rasa kekhawatiran amal kebaikan ditolak atau diterima disisi-Nya.

Data hasil penelitian tentang implementasi supervisi bebasis keikhlasan model menyukai amal kebaikan dilaksanakan secara sembunyi-sembunyi dari pada dipamirkan menunjukkan bahwa: pertama pengawas PAI tidak senang atau tidak menyukai prestasi kerja atau amal kebaikan dipamir-pamirkan kepada orang lain, karena sikap yang demikian dapat mendatang keangkuhan dan kesombongan pada diri sendiri dan orang lain, juga bisa berimbas kepada sikap riya dan takabbur kepada-Nya, kedua sangat menghindari diri dari membanggakan diri kepada orang lain terhadap apa yang telah diperbuatnya, karena dapat mendatangkan keangkuhan dan kesombongan pada diri sendiri dan pada orang lain, dan ketiga pengawas PAI selalu muncul rasa kekhawatiran amal kebaikan ditolak atau diterima disisi-Nya, kemudian terus memperkuat keyakinan setiap usaha yang maksimal dikerjakan akan diterima sebagai amal ibadah disisiNya, dan menjadi amal kebaikan di dunia dan di akhirat kelak, dan terus berusaha sekuat tenaga sesuai menurut ketentuan agama dan petunjuk teknis yang berlaku.

Dalam upaya mengimplementasikan supervisi model menyukai amal kebaikan secara sembunyi-sembunyi dari pada dipamirkan, maka pengawas PAI di SMP Negeri Kabupaten Nagan Raya perlu melakukan hal-hal sebagai berikut:

a. Dilarang memamirkan amal kebaikan dalam bekerja

Pengawas PAI dalam mengoperasionalkan tupoksi supervisi kepada guru PAI dilarang memamirkan amal kebaikan, karena memamirkan amal kebaikan itu bagian dari sifat riya. Riya adalah melakukan amal kebaikan dengan niat bukan karena Allah, akan tetapi ingin mendapat pujian, dikagumi, atau ingin dilihat oleh orang lain. Riya sebagai "syirik kecil" (syirkul ashghar), yakni menyekutukan-Nya dalam skali kecil.

b. Tidak merasa bangga karena telah berbuat kebaikan

Pengawas PAI yang berjiwa ikhlas tidak merasa bangga karena telah kebaikan untuk masyarakat, dan lembaga karena menghilangkan pahalanya, dan mendatang riya serta tekabbur. Ia tidak ada perasaan yang menganggab dirinya yang paling benar dan hebat, yang terpatri dalam jiwanya bahwa 
amal kebaikan itu karena berkat pertolongan-Nya, dan bukan karena usahanya semata. Selanjut ia tidak mau mengatakan itu hasil kerjanya, dan tidak mau pula mengatakan amal kebaikan itu untuk-Nya. Karena Allah tidak membutuhkan amal ibadah hamba-Nya, dan tidak pula membutuhkan kepada makhlukNya karena Allah maha kaya segala-gala-Nya.

c. Merasa khawatir amalnya ditolak oleh-Nya

Pengawas PAI yang berjiwa mukhlisin sangat merasa khawatir amalnya di tolak oleh-Nya. Walaupun usahanya sudah dilaksanakan dengan sungguh-sungguh, tetapi tetap saja mengharap pertolongan kepada-Nya, karena ia khawatir kalau-kalau amal ibadahnya tidak diterima oleh-Nya. Bahkan ia beranggapan amal yang telah dilakukan tidak pantas diterima oleh-Nya, karena serba kekurangan dan cacat dalam ibadahnya.

Ketiga indikator tersebut di atas harus dijadikan sebagai prinsip dasar bagi pengawas PAI dalam bekerja, dimana dalam mejalankan tugas supervisi sangat menyukai amal kebaikan dilaksanakan secara sembunyi-sembunyi dari pada dipamirkan, dengan cara menghindari untuk tidak memamirkan amal kebaikan kepada orang lain, dan tidak merasa bangga karena telah berbuat kebaikan serta merasa khawatir amalnya di tolak oleh-Nya.

\section{Model Bekerja Bukan Mencari Keuntungan}

Pengawas PAI yang berijwa ikhlas tidak terpetik sedikitpun di hatinya untuk mencari keuntungan kepentingan pribadi dan kelompok pada saat menjalankan tugasnya, melainkan ia bekerja untuk kepentingan lembaga, dan mencari keredhaan-Nya. Ia senantiasa dalam bekerja tidak mengharap pamrih dan pujian dari pimpinan, guru PAI dan publik, karena perilaku yang demikian dapat merusak amal ibadah, melemahkan semangat kebersamaan dan mendatangkan fitnah dari orang lain. Kemudian ia terus bekerja maksimal untuk meraih prestasi dalam meningkatkan kualitas kinerja guru PAI.

Data pada hasil penelitian tentang implementasi supervisi bebasis keikhlasan model bekerja bukan mencari keuntungan, tetapi mencari keredhaan-Nya menunjukkan bahwa: pertama pengawas PAI senantiasa mengesampingkan kepentingan pribadi, kelompok, dan lembaganya pada saat menjalankan tupoksi supervisi kepada guru PAI, kedua pengawas PAI sangat 
menghindari sikap dan perilaku mengharap pamrih dan pujian dari pimpinan, guru PAI dan publik, karena ia sangat meyakini dapat merusak amal ibadah, melemahkan kebersamaan dan mendatangkan fitnah, dan ketiga pengawas PAI selalu berusaha maksimal dalam menjalankan tupoksi supervisi supaya mendapat hasil yang memuaskan dalam peningkatan kualitas proses pembelajaran, dan pengembangan profesi guru PAI.

Dalam upaya mengimplementasikan model bekerja bukan mencari keungtungan, tetapi mencari keredhaan-Nya, maka pengawas PAI di SMP Negeri Kabupaten Nagan Raya perlu melakukan hal-hal sebagai berikut:

a. Bekerja bebas dari kepentingan pribadi, dan kelompok

Pengawas PAI dalam bekerja harus bebas dari kepentingan pribadi, dan kelompok pada saat mengoperasionalkan tupoksi supervisi kepada guru PAI. Bebas dari kepentingan pribadi, dan kelompok hal yang sangat perlu diinternalisasikan dalam jiwa pengawas PAI pada saat membimbing, membantu dan memperbaiki kinerja guru PAI. Ia berusaha menghadirkan wajah-Nya pada saat bekerja, dengan cara mencegah sifat rakus terhadap kepentingan dunia, dan menghindari diri dari sifat putus asa, pujian dan sanjungan, serta bersikap zubudlah terhadap semua kemewahan duniawi (Kitab "al-Fawa-id", tth: 150).

b. Bekerja tidak mengharap pamrih dan pujian dari manusia

Pengawas PAI yang ikhlas bekerja tidak mengharap pamrih dan pujian pada saat menjalankan tupoksi supervisi kepada guru PAI. Ia tidak tergores sedikitpun di hatinya mengharap pamrih dan pujian dari manusia, bahkan ia merasa takut kalau-kalau perbuatannya jatuh kepada syirik serta ditolak semua amal perbuatan oleh-Nya. Hal ini dengan pendapat Imam Ibnul Qayyim yang menjelaskan bahwa pernyakit buruk menjadi penghalang keikhlasan, yaitu yaitu: membuang sifat rakus, dan bersikap zuhud terhadap pujian dan sanjungan dari manusia. (Kitab "al-Fawa-id", tth: 150).

c. Berusaha sekuat tenaga untuk meningkatkan kualitas kerja

Pengawas PAI pada saat mengoperasionalkan tugas pokok dan fungsi supervisi kepada guru PAI senantiasa berusaha sekuat tenaga untuk meningkatkan kinerja guru PAI, dengan cara membimbing dan membina guru PAI serta mencegah dari hal-hal yang dapat memperturutkan hawa nafsu, dan terjerumus kepada kemaksiatan, seperti menerima 
hadiah, kolusi, dan nepotisme, karena semua itu dapat mengkhianati diri sendiri dan orang lain.

Ketiga indikator tersebut di atas harus dijadikan sebagai prinsip dasar bagi pengawas PAI, dimana dalam mejalankan tugas supervisi tidak boleh mencari keuntungan, tetapi mencari keredhaan Allah dengan cara dalam bekerja bebas dari kepentingan pribadi, dan kelompok, dalam bekerja tidak mengharap pamrih dan pujian dari manusia serta terus berusaha sekuat tenaga untuk menigkatkan kualitas kinerjanya.

\section{Model Merasa Senang Terhadap Orang Melebihi Dirinya}

Pengawas PAI yang berjiwa ikhlas sangat senang menerima masukan, saran dan kritikan yang bersifat konstuktif dari berbagai pihak, terutama dari pimpinan, dan rekan kerjanya. Ia selalu berprasangka baik, dan menyenangkan hati orang lain kapan saja dan dimana saja. Kemudian ia berusaha seoptimal mungkin untuk menjaling kerja sama dengan orang lain sudah mudah dalam berkoordinasi dan berkonsultasi dalam menjalankan program supervisi peningkatan kinerja guru PAI.

Data hasil penelitian tentang implementasi supervisi bebasis keikhlasan model merasa senang terhadap orang yang melebihi dirinya menunjukkan bahwa: pertama pengawas PAI sangat senang menerima masukan, saran dan kritikan yang bersifat konstuktif yang disampaikan oleh Kasi Pendis, guru PAI dan stakeholder lainnya, dalam rangka meningkatkan kualitas pelaksanaan proses supervisi kepada guru PAI dan pengembangan profesi guru PAI, kedua pengawas PAI selalu berprasangka baik kepada guru PAI, rekan kerja, kepala sekolah dan stakeholder lainnya pada saat melaksanakan tugas supervisi, walaupun ada hanya sebatas menunjukkan sikap jengkel dihatinya dikala tidak mau patuh dan tunduk kepada aturan yang berlaku. dan ketiga pengawas PAI perlu menjaling kerja sama dengan para guru PAI, kepala sekolah, dan Kasi Pendis dalam meningkatkan kinerja guru PAI, karena dengan bekerja sama akan mempermudah dan mempercepat proses pelaksanaan tugasnya.

Dalam upaya mengimplementasikan model supervisi merasa senang terhadap orang yang melebihi dirinya, maka pengawas PAI di SMP Negeri Kabupaten Nagan Raya perlu melakukan hal-hal sebagai berikut: 
a. Bersedia menerima masukan, saran dan kritikan dari orang lain

Pengawas PAI yang berjiwa ikhlas dalam mengoperasionalkan tupoksi supervisi kepada guru PAI sangat menyadari terhadap kekurangan dan kelebihan yang dimilikinya. Kelebihan yang ada bukanlah untuk merendahkan, mengejek, dan menjatuhkan orang lain, akan tetapi bagaimana memanfaatkan kelebihan itu menjadi modal dalam peningkatan kinerja guru PAI. Kemudian kekurangan yang dimilikinya diterima dengan senang hati dan berusaha saling melengkapi dan menutupi satu dengan lainnya. Selanjutnya ia rela mengundurkan diri dalam keadaan ridha, dan mengutamakan orang lain dari pada dirinya dalam keadaan taat, dan bahagia. (Ustad Jeffry, th: 1-5).

b. Bekerja berprasangka baik terhadap orang lain

Pengawas PAI yang berjiwa mukhlisin pada saat melaksanakan tugas supervisi peningkatan kinerja guru PAI senantiasa berprasangka baik kepada guru PAI, karena berprasangka buruk akan mempersulit dalam pembinaan dan perbaikan kinerja guru PAI, apalagi kalau sampai pada tingkat mencari-cari kesalahannya, sebagaimana sabda Rasulullah yang artinya: "Jauhilah prasangka buruk, karena prasangka buruk adalah ucapan yang paling dusta." (HR Bukhari).

c. Mudah bekerja sama dengan pihak lain dalam bekerja

Pengawas PAI yang berjiwa ikhlas senantiasa mengedepankan unsur bekerja sama dengan pihak lain pada saat mengoperasionalkan tupoksi supervisi kepada guru PAI. Ia melihat dengan bekerja sama dengan pihak lain dalam bekerja, maka akan mudah mendapat kepastian dan kekuatan lebih dari pada pekerjaan dilakukan secara individual. Karena dengan bekerja sama akan mudah dikerjakan serta terkumpul dan tercipta kekuatan besar dalam bekerja.

Ketiga indikator tersebut di atas harus dijadikan sebagai prinsip dasar bagi pengawas PAI, dimana dalam mejalankan tugas supervisi sangat senang kepada orang-orang yang melebihi dirinya, sehingga ia rela menerima masukan, saran, dan kritikan dari orang lain, serta selalu berprasangka baik terhadap orang lain, dan mudah bekerja sama dengan semua pihak dalam bekerja. 


\section{Kesimpulan}

Berdasarkan data hasil temuan dan pembahasan tersebut diatas, dapat ditarik kesimpulan bahwa pengawas PAI sudah mengimplementasikan model supervisi berbasis keikhlasan peningkatan kinerja guru PAI melalui model rasa takut kepada kemasyhuran, dan sanjungan karena membawa fitnah, model menganggab dirinya hina dihadapan-Nya, model menyukai amal kebaikan secara senbunyi-sembunyi dari pada dipamirkan, model tidak mencari keuntungan, tetapi mencari keredhaan-Nya, dan dan model senang terhadap orang melebihi dirinya. Efektifitas pendekatan ini belum terlihat dalam keseharian terhadap sikap dan perilaku mareka bekerja dengan penuh keikhlasan dalam meningkatkan kinerja guru PAI di sekolah umum.

Kesimpulan hasil penelitian ini direkomendasikan kepada pengawas PAI bahwa model-model supervisi berbasis keikhlasan tersebut dapat dilaksanakan dengan penuh rasa tanggung jawab, disipin, dan amanah supaya kinerja guru PAI betul-betul dapat meningkat dengan optimal. Kemudian dalam pelaksanaan supervisi tersebut dapat bekerja sama dengan kepala sekolah, dan stakeholder lainnya pada saat mengimplementasikan model supervisi berbasis keikhlasan dalam peningkatan kinerja guru PAI. 


\section{DAFTAR PUSTAKA}

Akhmad Sudrajat, (2009), Dimensi Kompetensi Supervisi Manajerial, Jakarta: Musyawarah kerja pengawas, tersedia: http//depdiknas, (diakses tanggal 22 Oktober 2018).

Agus Maimun dan Agus Zainul Fitri, (2010) Madrasah Unggulan Lembaga Pendidikan Alternatif di Era Kompetitif, Malang : UIN MALIKI PRESS.

Ali Imron, (2011), Supervisi Pendidikan Tingkat Satuan Pendidikan, Jakarta : PT. Bumi Aksara.

Departemen Agama RI, (2005), Kepengawasan Pendidikan, Jakarta: Dirjen Kelembagaan Agama Islam, Direktorat Madrasah dan Pendidikan Agama Islam pada Sekolah Umum.

Fadhlina Arief Wangsa, 2012), Konsep Ikblas Dalam Al-Qur'an (Kajian Tafsir Tematik Surat Al-Ikblas), ( Yossudarso Makassar: Jurusan Tafsir hadisFakultas Ushuluddin dan filsafat, Volume 6 Nomor 1.

Farid Mashudi, (2013), Panduan Evaluasi \& Supervisi Bimbingan danKonseling, Jogjakarta: Diva Press.

Fauzan Muslim, (tth). Manfaat Beristiqamah Dalam Hidup, https//:fauzanmuslimdahlan.wordprss.com /2014/07/20/ manfaat-beritiqamah-dalam-hidup/, (diakses 2 November 2018).

Kitab "al-Fawa-id", (tth), https://muslim.or.id/13945-jangan-nodaiibadah-anda-dengan-niat-duniawi.html), (diakses 2 Nopember 2018).

Lu'luatul Chizanah, (2011), "Ikhlas = Prososial?", dalam Jurnal Psikologi Islam (JPI) Lembaga Penelitian Pengembangan Psikologi dan Keislaman (LP3K), Vol 8 No. 2.

Lexy J. Moleong, (2001), Metode Penelitian Kualitatif, Bandung: Remaja Rosdakarya.

Muhtar \& Iskandar, (2009), Orientasi Baru Supervisi Pendidikan, Jakarta: Gaung Persada Press, cet.1.

Muhammad Fathurrohman, (2015), Budaya Religius Dalam Peningkatan Mutu Pendidikan: Tinjauan Teoritik dan Praktik Kontekstualisasi Pendidikan Agama di Sekolah, Yogyakarta, Kalimedia.

O Sholehuddi, dkk, (2009), Mengembangkan Budaya Kerja Melalui Pengawasan Dengan Pendekatan Agama, Model 1-5, Jakarta: Departemen Agama RI, Inspektorat Jenderal, Cet. Kedua.

Piet A. Sahertian, (2008), Konsep Dasar \& Teknik Supervisi Pendidikam, Jakarta: PT Rineka Cipta. 
Ustad Jeffry, (tth), Ciri-Ciri Orang-Orang Ikhlah dalam Agama, http://fikrah.interaktif.tripod.com/agama/ ciri_Ibadah.htm (diakses 22 Oktober 2018)

Ustad Jeffry, (tth), http://www.tribunnews.com/ramadhan/2012/08/06/ciri-ciriorang-ikhlas?page $=2$ (diakses 22 Oktober 2018)

Yusuf Al-Qardhawy, (1997), Niat dan Ikblas, Jakarta: Pustaka Alkautsar.

Yusuf Qardawi, (1996), Ikblas Sumber Kekuatan Islam, Jakarta: Gema Insani, Cet. I. 